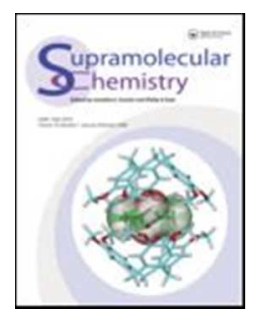

\title{
Novel uranyl(VI) complexes incorporating ethynyl groups as potential halide chemosensors: an experimental and computational approach.
}

\begin{tabular}{|r|l|}
\hline Journal: & Supramolecular Chemistry \\
\hline Manuscript ID & GSCH-2017-0062 \\
\hline Manuscript Type: & Special Issue Paper \\
\hline Date Submitted by the Author: & $15-$ May-2017 \\
\hline Complete List of Authors: & $\begin{array}{l}\text { DallaCort, Antonella; Università di Roma La Sapienza, Dept. of Chemistry } \\
\text { Rodriguez, Laura; Universitat de Barcelona, Secció de Química Inorgànica, } \\
\text { Departament de Química Inorganica i Química Orgànica } \\
\text { Yafteh Mihan, Francesco; Università di Roma La Sapienza, Dept. of } \\
\text { Chemistry } \\
\text { Bartocci, Silvia; Università di Roma La Sapienza, Dept. of Chemistry } \\
\text { Bosque, Ramon; Universitat de Barcelona, Secció de Química Inorgànica, } \\
\text { Departament de Química Inorganica i Química Orgànica } \\
\text { Sabaté, Ferran; Universitat de Barcelona, Inorganic Department }\end{array}$ \\
\hline Keywords: & halide recognition, metal salophen, uranyl \\
\hline \multicolumn{2}{|c}{} \\
\hline
\end{tabular}


1

2

3

4

5

6

7

8

10

11

12

13

14

15

16

17

18

19

20

21

22

23

24

25

26

27

28

29

30

31

32

33

34

35

36

37

38

39

40

41

42

43

44

45

46

47

48

49

50

51

52

53

54

55

56

57

58

59

60

Novel uranyl(VI) complexes incorporating ethynyl groups as potential halide chemosensors: an experimental and computational approach

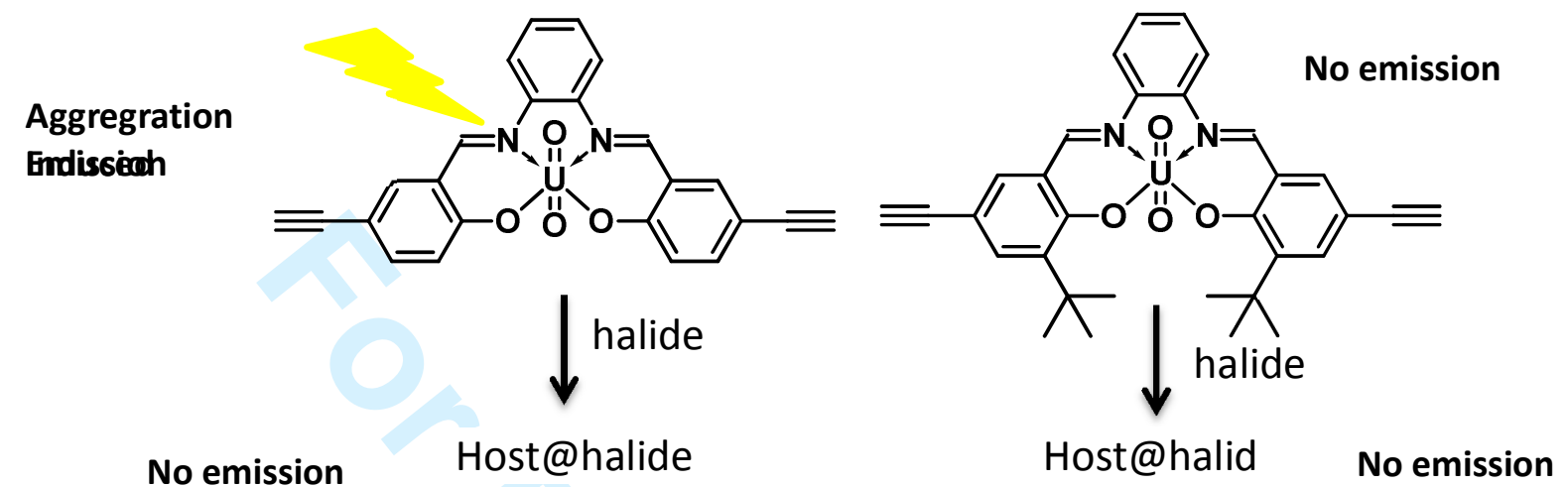

Halide $=\mathrm{F}, \mathrm{Cl}, \mathrm{Br}$ 


\title{
Novel uranyl(VI) complexes incorporating ethynyl groups as potential halide chemosensors: an experimental and computational approach
}

\author{
Silvia Bartocci ${ }^{\mathrm{a}}$, Ferran Sabaté ${ }^{\mathrm{b}}$, Francesco Yafteh Mihan ${ }^{\mathrm{a}}$, Ramon \\ Bosque $^{\mathrm{b}}$, Laura Rodríguez ${ }^{\mathrm{b}, \mathrm{c}^{*}}$ and Antonella Dalla Cort ${ }^{\mathrm{a}}$ \\ ${ }^{a}$ Dipartimento di Chimica and IMC-CNR Sezione Meccanismi di Reazione, Università \\ La Sapienza, 00185 Roma, Italy \\ ${ }^{b}$ Secció de Química Inorgànica, Departament de Química Inorganica i Química \\ Orgànica, Universitat de Barcelona, Martí i Franques 1-11, 08028 Barcelona, Spain \\ ${ }^{c}$ Institute of Nanoscience and Nanotechnology (IN2UB), Universitat de Barcelona
}

E-mail: Antonella.Dallacort@uniroma1.it

URL: http:/mc.manuscriptcentral.com/tandf/gsch Email: gsch-peerreview@tandf.co.uk 


\begin{abstract}
The synthesis of two novel Uranyl-salophen complexes, 1 and 2, decorated with ethynyl substituents, and the study in chloroform of their binding properties toward three different tetrabutylammonium halide salts, i.e. fluoride, chloride, bromide, are here reported. Such derivatives proved to be efficient halide receptors. The presence of two ethynyl groups in the para position, with respect to the phenoxide oxygens, seemed to be accountable for the moderate emission shown by complex 1. Surprisingly, instead, complex 2 does not show such property. The possibility of $\mathbf{1}$ to form dimers in non-coordinating solvents provides an explanation for such difference, since emission can be induced by the aggregation. This finding provides an unprecedented example of aggregation induced emission (AIE) for metal salophen derivatives.

Moreover DFT calculations provide theoretical insight to the formation of hostguest complexes. Their stabilities were calculated in vacuum and in chloroform and the results are perfectly in agreement with the experimental data.
\end{abstract}

Keywords: halide recognition, metal salophen, uranyl 


\section{Introduction}

Nowadays a main focus of supramolecular chemistry is the design and study of luminescent and colorimetric sensors for anions ${ }^{1}$. It is well known that anions play an essential role in many chemical and biological processes. Inorganic and biotic anions such as acetate, phosphate, and halide are involved in the activity of enzymes, transport of hormones, protein synthesis, and DNA regulation. Moreover, environmentally important anions such as nitrate and phosphate constitute a large part of current pollutants that cause eutrophication of rivers. For these reasons, over recent years, we have seen the development of a huge number of artificial anion receptors that can act as chemosensors, efficiently changing their photophysical properties in the presence of anions, and showing high sensitivity and low detection limit. Different types of noncovalent interactions are exploited to achieve recognition, ranging from hydrogen bond, anion- $\pi$ interactions to hydrophobic effects etc. ${ }^{2,3,4}$ Within these, an important binding motif is metal coordination, that has its roots in classical coordination chemistry. ${ }^{5}$

Among the different metals that can be coordinated by these ligands, there is the hexavalent uranyl dication, $\mathrm{UO}_{2}{ }^{2+}$ which displays a pentagonal bipyramidal coordination geometry in which the apical positions are occupied by the two oxygen atoms, while four of the five equatorial positions are engaged with the $\mathrm{N}_{2} \mathrm{O}_{2}$ donor atoms. Thus an equatorial position remains available for substrates that can be complexed through Lewis acid-base interactions. ${ }^{6}$ It was found that such complexes behave as highly efficient receptors for anions. The recognition event can be easily detected by UV-vis or NMR spectroscopy following variations induced by the presence of the anion. Unfortunately, although uranyl acetate and salophen ligand are fluorescent on their own, the corresponding complex hardly emits ${ }^{7,8}$ preventing the use of these complexes as fluorescent sensors. In the literature several approaches have been 
pursued to face the problem of having very good receptors for specific targets, although not emissive thus precluding their use in sensing. To overcome these problems different strategies have been adopted including for example the attachment to the ligand molecular framework of anthracene ${ }^{9}$ and/or pyrene units ${ }^{10}$ with high fluorescence quantum yields $\left(\Phi_{\mathrm{F}}\right)$, or the extension of $\pi$-conjugation and the introduction of electron withdrawing groups ${ }^{11}$ as substituents. ${ }^{12}$

Such considerations have prompted us toward the synthesis of two new uranylsalophen complexes, 1-2, bearing ethynyl substituents as chromophoric groups. Here we report the synthesis of such derivatives and how the introduction of the ethynyl substituents on the ligand skeleton affects their association behavior toward a series of halides, fluoride, chloride and bromide, and their photoluminescent properties.

(Figure 1)

\section{Results and Discussion}

\section{Syntheses}

The new compounds were obtained according to Scheme 1.

\section{Scheme 1}

5-bromo-2-hydroxybenzaldehyde is commercially available, while 5-bromo-3-tertbutyl-2-hydroxybenzaldehyde, $\mathbf{3 b}$, was prepared according to Scheme 2. Compounds $\mathbf{4 a}$ and $\mathbf{4 b}$ were obtained through Sonogashira coupling reactions ${ }^{13}$ between the proper hydroxybenzaldehyde, $\mathbf{3 a}$ or $\mathbf{3 b}$, ethynyltrimethylsilane in the presence of bis(triphenylphosphine)palladium(II) dichloride and copper iodide in trimethylamine. After deprotection, derivatives $\mathbf{5 a}$ and $\mathbf{5} \mathbf{b}^{14}$ were reacted with 1,2-phenylendiamine in 
the presence of $\mathrm{UO}_{2}(\mathrm{OAc})_{2} \cdot 2 \mathrm{H}_{2} \mathrm{O}$ in methanol. After $24 \mathrm{~h}$ at room temperature, a bright orange powder, $\mathbf{1}$, or a red powder, $\mathbf{2}$, were obtained and isolated without further purification (SI).

Scheme 2

\section{Results and discussion}

Absorption spectra of the uranyl complexes display different bands between $300-450 \mathrm{~nm}$ which can be assigned to $\pi \rightarrow \pi^{*}$ transitions of the phenyl ring and of the azomethine chromophore. The farthest energy band is assigned to $n \rightarrow \pi^{*}$ transition involving the promotion of the lone pair electrons of nitrogen atom to the anti-bonding $\pi^{*}$ orbital. $^{15}$

The appearance of an emission band in the case of 1 with a maximum at $479 \mathrm{~nm}$ characterized by moderate quantum yield $\left(\Phi_{\mathrm{F}}=0.021 \pm 0.001\right)$ in chloroform, Figure 2, let us think that this was due to the introduction of ethynyl groups.

Before starting an exploratory study of the affinity of $\mathbf{1}$ towards a series of halides based on emission variations, we performed standard UV-vis titrations measuring absorption variations in $\mathrm{CHCl}_{3}$ using tetrabutylammonium (TBA) salts of fluoride, chloride and bromide.

The addition of increasing amount of standard solutions of the TBA salt in chloroform to the solution of $\mathbf{1}$, caused variations of the absorbance spectrum, see Fig 3 due to the well known strong affinity of uranyl salophen complexes towards halides. ${ }^{16}$

The appearance of an emission band in the case of 1 with a maximum at $479 \mathrm{~nm}$ characterized by moderate quantum yield $\left(\Phi_{\mathrm{F}}=0.021 \pm 0.001\right)$ in chloroform, Figure 2 , let us think that this was due to the introduction of ethynyl groups. 
Before starting an exploratory study of the affinity of $\mathbf{1}$ towards a series of halides based on emission variations, we performed standard UV-vis titrations measuring absorption variations in $\mathrm{CHCl}_{3}$ using tetrabutylammonium (TBA) salts of fluoride, chloride and bromide.

The addition of increasing amount of standard solutions of the TBA salt in chloroform to the solution of $\mathbf{1}$, caused variations of the absorbance spectrum, see Fig 3 due to the well known strong affinity of uranyl salophen complexes towards halides. ${ }^{17}$

(Figure 2)

(Figure 3)

Typical titration experiments are reported in Figure 3. Reproducible absorbance changes in the $280-550 \mathrm{~nm}$ region caused by the enhancement of anion concentration at $25^{\circ} \mathrm{C}$ were observed. The presence of sharp isosbestic points and the close adherence of titration data to the binding isotherm of a 1:1 complexation phenomenon lead to estimate association constants higher than $10^{6} \mathrm{M}^{-1}$ for fluoride and $10^{5} \mathrm{M}^{-1}$ for chloride. Instead in the case of $\mathrm{TBABr}$, the titrations data were not reproducible and the values obtained appeared to be dependent on complex concentration, i.e. in the host concentration range of $5 \cdot 10^{-5}-5 \cdot 10^{-6} \mathrm{M}$, the calculated association constants assume values between $3 \cdot 10^{3}$ and $2 \cdot 10^{4} \mathrm{M}^{-1}$.

In 2007 Ikeda et al. reported that in non-coordinating solvents like chloroform, Uranylsalophen complexes without substituents in the ortho position to the phenolic oxygens are present as dimeric complexes $\left[\left(\mathrm{UO}_{2}(\text { salophen })\right]_{2}\right.$ even at low concentration $\left(10^{-5}-10^{-}\right.$ $\left.{ }^{6} \mathrm{M}\right) .{ }^{18}$ In the dimer, the two salophen units are held together through the coordination of the phenoxide oxygen of one salophen ligand to the fifth equatorial coordination site 
of the other Uranyl center. Likely this occurs also in the case of complex 1. This assumption is confirmed by the ${ }^{1} \mathrm{H}-\mathrm{NMR}$ spectrum in $\mathrm{CDCl}_{3}$ in which the aromatic signals appear quite broad. Indeed the addition of a small amount of a competitive guest, for example one or two drops of a coordinating solvent such as pyridine, leads to a well resolved spectrum characterized by sharp signals. To avoid dimerization, a likely reason for the irreproducibility of measurements in the case of weaker binders, we introduced two tert-butyl groups in the 3,3' positions, 2. UV-vis titrations with the three TBA halides, $\mathrm{F}^{-}, \mathrm{Cl}^{-}$, and $\mathrm{Br}^{-}$, were performed using this time complex 2 . Very good affinities for fluoride and chloride, with association constants higher than $10^{6}$ and $10^{5}$ $\mathrm{M}^{-1}$, respectively, were measured, Table 1, and accurate, although lower values, as expected, were obtained in the case of bromide, i.e. $7 \cdot 10^{3} \mathrm{M}^{-1}$ (Figure 5). These data are perfectly reproducible and independent of host concentration. Moreover unexpectedly no emission was observed in this case.

(Figure 4)

(Table 1)

Thus the absence of substituents close to the metal center in complex $\mathbf{1}$ favors the formation of dimers even in diluted solution. Since fluoride and chloride bind very strongly to uranyl, their additions immediately disrupt dimeric aggregates shifting the equilibrium completely toward the monomeric species. This leads to reliable and reproducible data for titrations as the model we apply is that of a 1:1 complexation phenomenon. ${ }^{19}$ Instead for bromide, that has a lower affinity for the metal, at least three orders of magnitude less, the equilibrium between monomeric and dimeric species, Equation 1, is more important and concentration starts playing a crucial role. Indeed for 
complex 1 the binding constant with bromide decreases upon increasing complex concentration while for complex $\mathbf{2}$, in which dimer formation is prevented, the hosthalide complex is formed immediately, and concentration is not influencing the measurements.

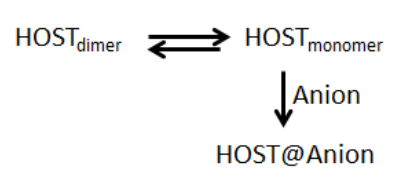

The unexpected finding that complex 2 does not show emissive properties suggests that the fluorescence that we observe for $\mathbf{1}$ should be ascribed to aggregation. Such phenomenon is known as aggregation-induced emission (AIE) and originates from the restriction of intramolecular rotation. ${ }^{20}$

\section{Molecular modelling}

In order to provide more theoretical insight into the geometry of the host-guest complexes as well as into the energy of their formation, molecular modeling studies were performed at the DFT level, using the B3LYP functional ${ }^{21,22}$ (see below). The minimum energy geometries of receptors $\mathbf{1}$ and $\mathbf{2}$ are displayed in Figure 5.

(Figure 5)

(Table 2)

As previously reported, the $\mathrm{U}-\mathrm{O}$ distance, is significantly longer than the one corresponding to the axial oxygens $(\mathrm{U}=\mathrm{O})$ due to the overlap between the $6 \mathrm{~d}$ and $5 \mathrm{f}$ orbitals of the uranium atom and the three $\mathrm{p}$ orbitals (or two $\mathrm{p}$ and one hybrid $\mathrm{sp}$ orbitals) of each axial oxygen providing the linear structure. ${ }^{23}$ 
The $\mathrm{O}=\mathrm{U}=\mathrm{O}$ moiety is almost linear, Table 2 . The two derivatives, $\mathbf{1 - 2}$, are expected to be folded with the aromatic substituted rings with a torsion angle of $43-45^{\circ}$ with respect to the main plane of the $\mathrm{U}-\mathrm{N}_{2} \mathrm{O}_{2}$ atoms (see Figure $\mathrm{S} 1$ ). This conformation would favour the coordination with guest molecules as no steric hindrance is expected around the fifth equatorial binding site of the metal.

Calculations on the halide complexes were also performed and the resulting structures and main distances and angles are shown in Figures 6, S2 and Table 3.

(Figure 6)

(Table 3)

Coordination with halides affects the environment around the metal atom and induces a slight deviation from $\mathrm{O}=\mathrm{U}=\mathrm{O}$ linearity (the angle becomes less than $180^{\circ}$ ). It should be noted that the $\mathrm{U} \cdots \mathrm{X}\left(\mathrm{X}=\mathrm{F}^{-}, \mathrm{Cl}^{-}, \mathrm{Br}^{-}\right)$calculated distances reproduce quite nicely those obtained from X-ray crystal diffraction in analogous host-guest uranyl-halide complexes. $^{24,25}$

The energies for the formation of the adducts with the different halides (fluoride, chloride and bromide) were calculated by DFT in the gas phase and in chloroform. The results are summarized in Table 4.

(Table 4)

Inspection of Table 3 confirms the experimental data. The affinity for fluoride anion is the highest for both receptors, following the general trend $\mathrm{F}^{-}>\mathrm{Cl}^{-}>\mathrm{Br}^{-}$and indeed, the predicted energy for the complex formation with the bromide anion is clearly lower in 
all cases. The energies predicted for the host:guest interactions with receptor $\mathbf{2}$ are larger than those calculated for $\mathbf{1}$. This is in agreement with the more stable monomeric species of complex $\mathbf{2}$, where the presence of the tert-butyl group precludes dimer formation. Additional non common halide $\cdots \mathrm{H}$ hydrogen bonding interactions, that could be established between the different halides and the tert-butyl groups, may favor the stability of the resulting adducts. ${ }^{26}$

\section{Conclusions}

Here, we reported the synthesis of two novel Uranyl-salophen complexes, $\mathbf{1}$ and $\mathbf{2}$, and the study in chloroform of their binding properties toward three different tetrabutylammonium halide salts, i.e. fluoride, chloride, bromide.

The presence of two ethynyl groups in the para position with respect to the phenoxide oxygens, seemed to be accountable for the appearance of moderate emission in $\mathbf{1}$. UVvis titration experiments highlighted the good affinity for TBAF $\left(\mathrm{K}>10^{6} \mathrm{M}^{-1}\right)$ and TBACl $\left(\mathrm{K}>10^{5} \mathrm{M}^{-1}\right)$ salts, while for $\mathrm{TBABr}$ measurements resulted to be not reproducible, depending on host concentration.

The possibility for $\mathbf{1}$ to form dimeric species in non-coordinating solvents provides an explanation for the irreproducibility as well as for the observed emission that can be induced by aggregation (AIE).

These considerations are supported by the fact that complex $\mathbf{2}$, in which the presence of two tert-butyl groups in the ortho position with respect to the phenoxide oxygens prevents dimer formation, shows association constants for fluoride and chloride, comparable with those obtained for $\mathbf{1}$. The binding affinity of 2 toward $\mathrm{TBABr}, \mathrm{K}=$ $7 \cdot 10^{3} \mathrm{M}^{-1}$, was, in this case, reproducibly measured and proved to be independent of receptor concentration. Moreover complex 2 did not have any emission spectrum confirming that the moderate fluorescence shown by $\mathbf{1}$ is indeed due to dimerization. 
DFT calculations provided theoretical insight into the formation of host-guest complexes. Their stabilities were calculated in vacuum and in chloroform and the results are in agreement with the experimental data since the energies for the host:guest interactions calculated in the case of receptor $\mathbf{2}$ are higher than those calculated for $\mathbf{1}$ where the different affinity strength towards halides, $\mathrm{F}^{-}>\mathrm{Cl}^{-}>>\mathrm{Br}^{-}$, influences the efficiency of dimer dissociation.

\begin{abstract}
Aknowledgements
L. R. and R.B. are grateful to the Ministerio de Ciencia e Innovación of Spain (AEI/FEDER, UE Projects CTQ2016-76120-P and CTQ2015-65040-P). S. B. gratefully acknowledges the CIRCC, Interuniversity Consortium of Chemical Catalysis and Reactivity for the fellowship. A.D.C. acknowledges the financial support of Università La Sapienza, project "Ricerca scientifica di Ateneo 2015”.
\end{abstract}




\section{References}

${ }^{1}$ a) P. A. Gale, C. Caltagirone Chem. Soc. Rev., 2015, 44, 4212-4227 and references therein; b) T. Gunnlaugsson, M. Glynn, G. M. Tocci, P. E. Kruger, F. M. Pfeffer Coord. Chem. Rev. 2006, 250,3094-3117.

${ }^{2}$ C. L. D. Gibb, B. C. Gibb J. Am. Chem. Soc. 2011, 133, 7344-7347.

${ }^{3}$ O. B. Berryman, V. S. Bryantsev, D. P. Stay, D. W. Johnson, B. P. Hay J. Am. Chem. Soc. 2007, 129, 48-58.

${ }^{4}$ E. V. Anslyn, D. A. Dougherty "Modern Physical Organic Chemistry", University Science Books Sausalito, USA.

5 a) K. Bowman-James, A. Bianchi and E. García-España Anion, Coordination Chemistry , Wiley-VCH, New York, 2012; b) E. J. O’Neil, B. D. Smith Coord. Chem. Rev. 2006, 250, 3068-3080.

${ }^{6}$ V. van Axel Castelli, A. Dalla Cort, L. Mandolini V. Pinto, D. N. Reinhoudt, F. Ribaudo, C. Sanna, L. Schiaffino, B. H. M. Snellink-Ruël Supramol. Chem., 2002, 14, 211-219; (b) M. Cametti, M. Nissinen, A. Dalla Cort, K. Rissanen, L. Mandolini Inorg. Chem., 2006, 45, 6099-6101.

${ }^{7}$ H. Kunkler, A. Vogler Verlag Z. Naturforsh 2002, 57b, 301-304.

${ }^{8}$ M. Hosseini, M. R. Ganjali, B. Veismohammadi, F. Faridbod, S. D. Abkenard, M. Salavati-Niasari Luminescence 2012, 27, 341-345.

${ }^{9}$ F. Yafteh Mihan, S. Bartocci, A. Credi, S. Silvi, A. Dalla Cort Supramol. Chem. 2012, 25, 1-8; b) L. Fabbrizzi and A. Poggi Chem. Soc. Rev. 1995, 24, 197-202.

${ }^{10}$ J. S. Kim, D. T. Quang Chem. Rev., 2007, 107, 3780-3799.

${ }^{11}$ S. Bartocci, F. Sabaté, R. Bosque, F. Keymeulen, K. Bartik, L. Rodríguez, A. Dalla Cort Dyes Pigm. 2016, 135, 94-101.

${ }^{12}$ X. Li, X. Gao, W. Shi, H. Ma Chem. Rev. 2014, 114, 590-659. 
${ }^{13}$ K.-H. Chang, C.-C. Huang, Y.-H. Liu, Y.-H. Hu, P.-T. Chou, Y.-C. Lin Dalton Trans. 2004, 1731-1738.

${ }^{14}$ A. L. Korich, T. S. Hughes Org. Lett. 2008, 10, 5405-5408

${ }^{15}$ V. van Axel Castelli, A. Dalla Cort, L. Mandolini, V. Pinto, D.N. Reinhoudt, F. Ribaudo, C. Sanna , L. Schiaffino, B.H.M. Snellink-Ruël, Supramol. Chem. 2002, $14,211-9$.

${ }^{16}$ a) M. M. G. Antonisse, B. H. M. Snellink-Ruël, A. C. Ion, J. F. J. Engbersen, D. N. Reinhoudt, J. Chem. Soc. Perkin Trans. 2, 1999, 1211 -1218; b) M.Brynda, T. A. Wesolowski, K. Wojciechowski, J. Phys. Chem. A 2004, 108,5091 -5099; c) M. Cametti, M. Nissinen, A. Dalla Cort, L. Mandolini, K. Rissanen J. Am. Chem. Soc. 2005,127, 3831-3837 d) M. Cametti, M. Nissinen, A. Dalla Cort, L. Mandolini, K. Rissanen J. Am. Chem. Soc. 2007, 129, 3641-3648; e) A. Dalla Cort, G. Forte, L. Schiaffino, J. Org. Chem. 2011, 76, 7569 -7572; f) E. Bodo A. Ciavardini, A. Dalla Cort, I. Giannicchi, F. Yafteh Mihan, S. Fornarini, S. Vasile, D. Scuderi, S. Piccirillo Chem. Eur. J. 2014, 20, 11783-11792; g) L. Leoni, R. Puttreddy, O. Jurcek, A. Mele, I. Giannicchi, F. Yafteh Mihan, K. Rissanen, A. Dalla Cort Chem. Eur. J. 2016, 22, 18714-18717.

17 a) M. M. G. Antonisse, B. H. M. Snellink-Ruël, A. C. Ion, J. F. J. Engbersen, D. N. Reinhoudt, J. Chem. Soc. Perkin Trans. 2, 1999, 1211 -1218; b) M.Brynda, T. A. Wesolowski, K. Wojciechowski, J. Phys. Chem. A 2004, 108,5091 -5099; c) M. Cametti, M. Nissinen, A. Dalla Cort, L. Mandolini, K. Rissanen J. Am. Chem. Soc. 2005,127, 3831-3837 d) M. Cametti, M. Nissinen, A. Dalla Cort, L. Mandolini, K. Rissanen J. Am. Chem. Soc. 2007, 129, 3641-3648; e) A. Dalla Cort, G. Forte, L. Schiaffino, J. Org. Chem. 2011, 76, 7569 -7572; f) E. Bodo A. Ciavardini, A. Dalla Cort, I. Giannicchi, F. Yafteh Mihan, S. Fornarini, S. Vasile, D. Scuderi, S. Piccirillo Chem. Eur. J. 2014, 20, 11783-11792; g) L. Leoni, R. Puttreddy, O. Jurcek, A. Mele, I. Giannicchi, F. Yafteh Mihan, K. Rissanen, A. Dalla Cort Chem. Eur. J. 2016, 22, 18714-18717.

URL: http:/mc.manuscriptcentral.com/tandf/gsch Email: gsch-peerreview@tandf.co.uk 
${ }^{18}$ K. Takao, Y. Ikeda Inorg Chem. 2007, 46, 1550-1562.

${ }^{19}$ P. Thordarson Chem. Soc. Rev., 2011, 40, 1305-1323.

${ }^{20}$ a) J. Mei, N. L. C. Leung, R. T. K. Kwok, J. W. Y. Lam, B. Z. Tang, Chem. Rev. 2015, 115, 11718-11940; b) D. Wang, S.-M. Li, J.-Q. Zheng, D.-Y. Kong, X.-J. Zheng, D.-C. Fang, L.-P. Jin Inorg. Chem., 2017, 56, 984-990.

${ }^{21}$ A. D. Becke J Chem Phys 1993, 98, 5648-5652.

${ }^{22}$ C. Lee, W. Yang, R.G. Phys Rev B, 1988, 37,785-789.

23 R. P. Venkateswara, C.P. Rao, A. Sreedhara, E.K. Wegelius, K. Rissanen, E.Kolehmainen J. Chem. Soc. Dalton Trans. 2000, 56, 1213-1218.

${ }^{24}$ M. Cametti, L. Ilander, A. Valkonen, M. Nieger, M. Nissinen, E. Nauha, K. Rissanen, Inorg. Chem. 2010, 49, 11473-11484.

25 M. Cametti , M. Nissinen, A. Dalla Cort, L. Mandolini , K. Rissanen Chem Commun. 2003, 2420-2421.

${ }^{26}$ L. Brammer, E. A. Bruton, P. Sherwood, Crystal Growth \& Design, 2001, 1, 277290.

URL: http:/mc.manuscriptcentral.com/tandf/gsch Email: gsch-peerreview@tandf.co.uk 
Table 1. Binding constants, $\mathrm{K}\left(\mathrm{M}^{-1}\right)$ of $\mathbf{1}$ and $\mathbf{2}$ toward TBAX salts $\left(\mathrm{X}=\mathrm{F}^{-}, \mathrm{Cl}^{-}, \mathrm{Br}^{-}\right)$in $\mathrm{CHCl}_{3}$ at $25^{\circ} \mathrm{C}$

\begin{tabular}{|lccc}
\hline Complex & $\mathbf{F}^{-}$ & $\mathbf{C l}^{-}$ & $\mathbf{B r}^{-}$ \\
\hline $\mathbf{1}$ & $>10^{6}$ & $>10^{6}$ & - \\
$\mathbf{2}$ & $>10^{5}$ & $>10^{5}$ & $7 \times 10^{3}$
\end{tabular}

Table 2. Main distances calculated for optimized geometries of compounds $\mathbf{1}$ and $\mathbf{2}$.

\begin{tabular}{|c|c|c|c|c|}
\hline \multirow[t]{2}{*}{ Complex } & Distance (Å) & \multicolumn{3}{|c|}{ Angle ( $\left(^{\circ}\right)$} \\
\hline & $\mathrm{U}=\mathrm{O} \quad \mathrm{U}-\mathrm{O} \quad \mathrm{U}-\mathrm{N}$ & $\mathrm{O}=\mathrm{U}=\mathrm{O}$ & U-O-C & U-NH-C \\
\hline 1 & $\begin{array}{lll}1.787 & 2.271 & 2.579\end{array}$ & 179 & 135.36 & 125.06 \\
\hline 2 & $\begin{array}{lll}1.787 & 2.274 & 2.563\end{array}$ & 179 & 137.69 & 124.86 \\
\hline
\end{tabular}

Table 3. Main distances calculated for optimized geometries of complexes $\mathbf{1}$ and $\mathbf{2}$ with fluoride, chloride and bromide.

\begin{tabular}{|c|c|c|c|c|c|c|c|}
\hline \multirow[t]{2}{*}{ Complex } & \multicolumn{4}{|c|}{ Distance $(\AA)$} & \multicolumn{3}{|l|}{ Angle ( ${ }^{\circ}$ ) } \\
\hline & U-X & $\mathrm{U}=\mathrm{O}$ & U-O & U-N & $\mathrm{O}=\mathrm{U}=\mathrm{O}$ & $\mathrm{U}-\mathrm{O}-\mathrm{C}$ & U-NH-C \\
\hline $\mathbf{1} \cdot \mathbf{F}$ & 2.115 & 1.797 & 2.380 & 2.757 & 172.26 & 136.16 & 125.08 \\
\hline $\mathbf{1} \cdot \mathrm{Cl}$ & 2.708 & 1.788 & 2.345 & 2.748 & 172.51 & 136.44 & 125.11 \\
\hline $1 \cdot \mathrm{Br}$ & 2.923 & 1.787 & 2.336 & 2.740 & 172.91 & 136.45 & 125.11 \\
\hline $2 \cdot \mathrm{F}$ & 2.141 & 1.798 & 2.372 & 2.713 & 173.46 & 137.16 & 124.31 \\
\hline $2 \cdot \mathrm{Cl}$ & 2.726 & 1.787 & 2.368 & 2.696 & 173.44 & 141.24 & 126.96 \\
\hline $2 \cdot \mathrm{Br}$ & 2.936 & 1.786 & 2.369 & 2.689 & 173.63 & 141.52 & 126.34 \\
\hline
\end{tabular}

URL: http:/mc.manuscriptcentral.com/tandf/gsch Email: gsch-peerreview@tandf.co.uk 
Table 4. $\Delta \mathrm{E}$ values $(\mathrm{kcal} / \mathrm{mol})$ calculated for the formation of $\mathbf{1}$ and $\mathbf{2}$ :halide adducts in gas phase and in $\mathrm{CHCl}_{3}$.

\begin{tabular}{lll}
\hline & Gas & $\mathbf{C H C l}_{\mathbf{3}}$ \\
\hline $\mathbf{1 - F}$ & -129.76 & -71.42 \\
$\mathbf{1 - C l}$ & -59.01 & -15.93 \\
$\mathbf{1 - B r}$ & -44.87 & -7.04 \\
$\mathbf{2 - F}$ & -135.35 & -83.73 \\
$\mathbf{2 - C l}$ & -61.71 & -24.94 \\
$\mathbf{2 - B r}$ & -46.12 & -14.83 \\
\hline
\end{tabular}


Figure 1. Structure of compounds $\mathbf{1}$ and $\mathbf{2}$.

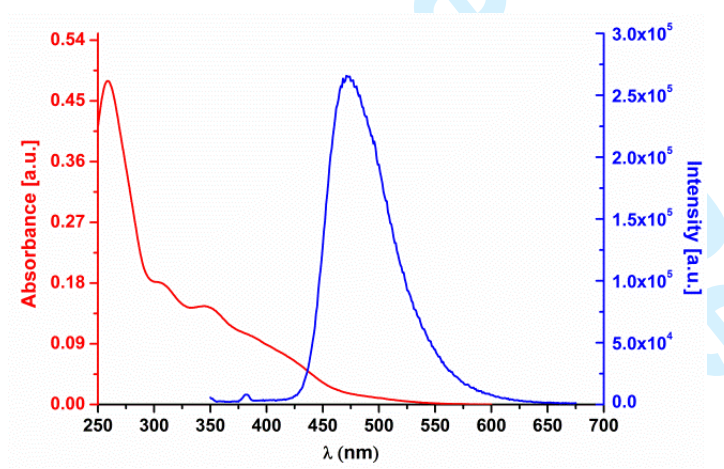

Figure 2. UV-Vis (red) and emission (blue) spectra of compound 1, c = 8.62 x 10-5 M, in $\mathrm{CHCl}_{3}$.

$$
\begin{aligned}
& \text { 1, } R=H \\
& 2, R=t-B u t
\end{aligned}
$$

$$
\text { in } \mathrm{CHCl}_{3} \text {. }
$$




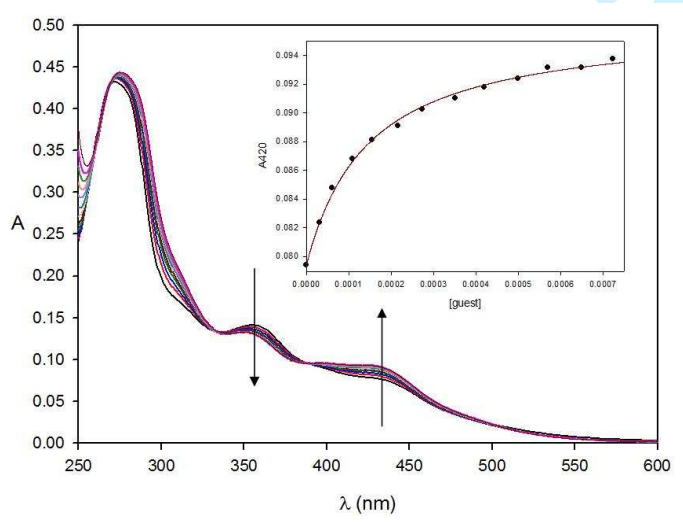

Figure 4. UV-vis titration curve in $\mathrm{CHCl} 3$ at $25^{\circ} \mathrm{C}$ of complex 2 (inset, points are experimental, curve is calculated) and corresponding spectral variation with $\mathrm{TBABr}$ ([2] $=9.36 \cdot 10-6 \mathrm{M})$. 

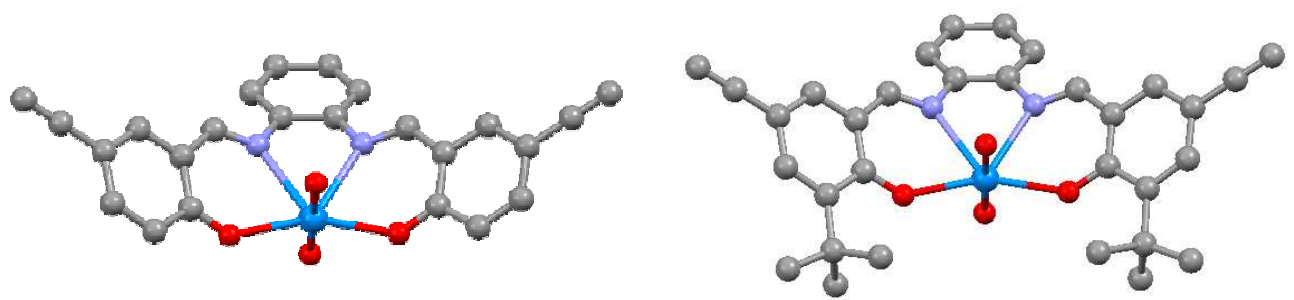

Figure 5. Optimized structures of 1 (left) and 2 (right). Carbon (grey); oxygen (red); uranium (cyan); nitrogen (blue). Hydrogens are omitted for clarity.
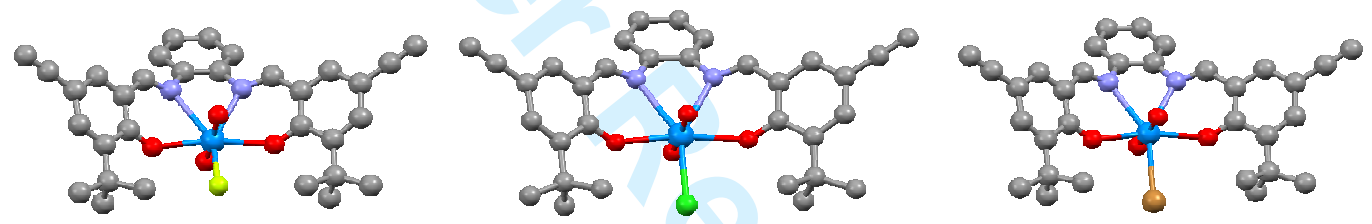

Figure 6. Molecular modeling structure of 2-F (left), 2-Cl (middle) and 2-Br (right). Hydrogens are omitted for clarity. Carbon (grey); oxygen (red); uranium (cyan); nitrogen (blue); fluoride (yellow); chloride (green) and bromide (brown). 
2

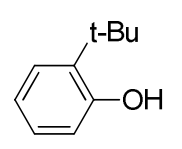

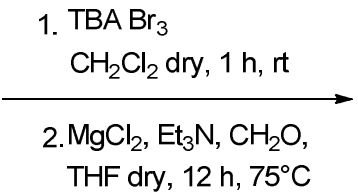

THF dry, $12 \mathrm{~h}, 75^{\circ} \mathrm{C}$ 3b, $\mathrm{R}=$

4

TBAF $1 \mathrm{M}$ in THF, AcOH
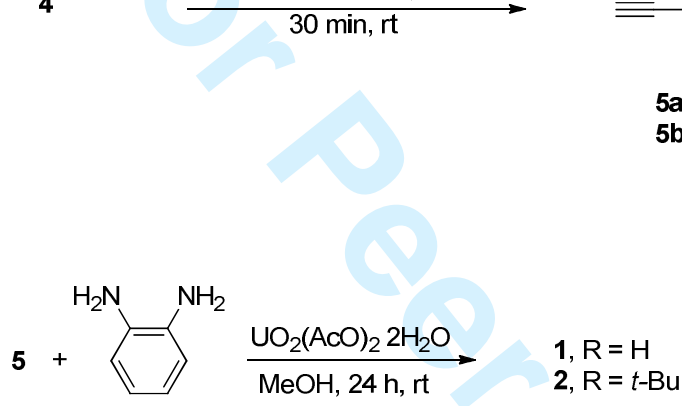

Scheme 1. Synthetic route to Uranyl-salophen complex 1-2.

Scheme 2. Synthetic route to 5-bromo-3-tert-butyl-2-hydroxybenzaldehyde, $\mathbf{3 b}$.

URL: http:/mc.manuscriptcentral.com/tandf/gsch Email: gsch-peerreview@tandf.co.uk 


\title{
Novel uranyl(VI) complexes incorporating ethynyl groups as potential halide chemosensors: an experimental and computational approach
}

\author{
Silvia Bartocci ${ }^{\mathrm{a}}$, Ferran Sabaté ${ }^{\mathrm{b}}$, Francesco Yafteh Mihan ${ }^{\mathrm{a}}$, Ramon \\ Bosque $^{\mathrm{b}}$, Laura Rodríguez ${ }^{\mathrm{b}, \mathrm{c}^{*}}$ and Antonella Dalla Cort ${ }^{\mathrm{a}}$ \\ ${ }^{a}$ Dipartimento di Chimica and IMC-CNR Sezione Meccanismi di Reazione, Università \\ La Sapienza, 00185 Roma, Italy \\ ${ }^{b}$ Secció de Química Inorgànica, Departament de Química Inorganica i Química \\ Orgànica, Universitat de Barcelona, Martí i Franques 1-11, 08028 Barcelona, Spain \\ ${ }^{c}$ Institute of Nanoscience and Nanotechnology (IN2UB), Universitat de Barcelona
}

\section{Supporting Information}

Caution! While isotopically depleted $U$ was used in these experiments, precautions for handling radioactive materials should be followed. 


\section{General Methods and Materials}

NMR spectra were recorded on a Brucker AC-200 and AC-300 MHz. GC-MS spectra were run on a GC Agilent Technologies $6890 \mathrm{~N}$ equipped with a $30 \mathrm{~m}$ x $0.25 \mathrm{~mm}$ x $25 \mu \mathrm{m}$ methyl silicone gum capillary column containing 5\% of phenyl-methyl-silicone (CPSIL8CB) coupled to a quadrupole detector 5973MSD Network operating at 70ev. High-resolution mass spectra (HRMS) were performed by an ESI-TOF spectrometer. 5-bromo-2-hydroxybenzaldehyde, $\left[\mathrm{PdCl}_{2}\left(\mathrm{PPh}_{3}\right)_{2}\right]$, CuI, ethynyltrimethylsilane, TBAF (1 $\mathrm{M}$ solution in THF), tetrabutylammoniumtribromide $\left(\mathrm{TBABr}_{3}\right)$, 2-(tert-butyl)phenol, paraformaldehyde 1,2phenilendiamine are commercially available and used without further purification.

\section{Syntheses}

2-hydroxy-5-((trimethylsilyl)ethynyl)benzaldehyde (4a). Under argon atmosphere, in a dry two-necked flask, 5-bromo-2-hydroxybenzaldehyde (1.01 g, $5.02 \mathrm{mmol}),\left[\mathrm{PdCl}_{2}\left(\mathrm{PPh}_{3}\right)_{2}\right](110$ $\mathrm{mg}, 0.16 \mathrm{mmol})$ and $\mathrm{CuI}(40 \mathrm{mg}, 0.21 \mathrm{mmol})$ were added. After five vacuum-argon cycles, 16 $\mathrm{ml}$ of triethylamine and $1.1 \mathrm{ml}(7.78 \mathrm{mmol})$ of ethynyltrimethylsilane were added and the mixture was stirred at $80^{\circ} \mathrm{C}$ for $3 \mathrm{~h}$. After cooling to room temperature, the mixture was filtered and the flask was washed with $\mathrm{CH}_{2} \mathrm{Cl}_{2}$. The crude product was purified, after removal the solvent under reduced pressure, by chromatographic column on flash silica gel $\left(\mathrm{Et}_{2} \mathrm{O}: \mathrm{Hex} 3: 2\right)$ affording to $912 \mathrm{mg}(4.18 \mathrm{mmol})$ of yellow solid with $83 \%$ of yield.

GC-MS m/z (+) $218(\mathrm{M}, 100 \%)$.

${ }^{1}$ H-NMR (300 MHz, CDCl $)$ ) $\delta: 11.09$ (s, 1H, OH), $9.84(\mathrm{~s}, 1 \mathrm{H}, \mathrm{O}=\mathrm{CH}), 7.69\left(\mathrm{~d}, 1 \mathrm{H}, \mathrm{Ph},{ }^{4} \mathrm{~J}_{\mathrm{H}-\mathrm{H}}=\right.$ $2.7 \mathrm{~Hz}), 7.59\left(\mathrm{dd}, 1 \mathrm{H}, \mathrm{Ph},{ }^{3} \mathrm{~J}_{\mathrm{H}-\mathrm{H}}=12.9 \mathrm{~Hz},{ }^{4} \mathrm{~J}_{\mathrm{H}-\mathrm{H}}=2.7 \mathrm{~Hz}\right), 6.92\left(\mathrm{~d}, 1 \mathrm{H}, \mathrm{Ph},{ }^{3} \mathrm{~J}_{\mathrm{H}-\mathrm{H}}=12.9 \mathrm{~Hz}\right)$, $0.23\left(\mathrm{~s}, 9 \mathrm{H}, \mathrm{CH}_{3}\right) .{ }^{13} \mathbf{C}-\mathbf{N M R}\left(75 \mathrm{MHz}, \mathrm{CDCl}_{3}\right) \delta: 195.8,160.6,139.9,137.1,119.8,117.7$, $117.7,102.2,93.0,-0.3$.

5-ethynyl-2-hydroxybenzaldehyde (5a). In a one-necked flask, $729 \mathrm{mg}$ (3.34 mmol) of $\mathbf{3}$ was added with $3.7 \mathrm{ml}$ (3.67 mmol, $1.1 \mathrm{eq})$ of TBAF (1 M solution in THF) and $191 \mu \mathrm{l}(3.34 \mathrm{mmol})$ of acetic acid. After $3 \mathrm{~h}$ under stirring at room temperature, the mixture was diluted with $20 \mathrm{ml}$ of $\mathrm{CH}_{2} \mathrm{Cl}_{2}$ and washed with water until $\mathrm{pH}=7$ of aqueous phase. The organic phase was dried over anhydrous $\mathrm{Na}_{2} \mathrm{SO}_{4}$ and filtered. The solvent was removed under reduced pressure obtaining $462 \mathrm{mg}$ (3.16 mmol) of a yellow solid. Yield 95\%.

GC-MS m/z (+) $176(\mathrm{M}, 100 \%)$.

${ }^{1}$ H-NMR $\left(300 \mathrm{MHz}, \mathrm{CDCl}_{3}\right) \delta: 11.10(\mathrm{~s}, 1 \mathrm{H}, \mathrm{OH}), 9.84(\mathrm{~s}, 1 \mathrm{H}, \mathrm{O}=\mathrm{CH}), 7.70\left(\mathrm{~d}, 1 \mathrm{H}, \mathrm{Ph},{ }^{4} \mathrm{~J}_{\mathrm{H}-\mathrm{H}}=\right.$ $2.1 \mathrm{~Hz}), 7.60\left(\mathrm{dd}, 1 \mathrm{H}, \mathrm{Ph},{ }^{3} \mathrm{~J}_{\mathrm{H}-\mathrm{H}}=8.7 \mathrm{~Hz},{ }^{4} \mathrm{~J}_{\mathrm{H}-\mathrm{H}}=2.1 \mathrm{~Hz}\right), 6.94\left(\mathrm{~d}, 1 \mathrm{H}, \mathrm{Ph},{ }^{3} \mathrm{~J}_{\mathrm{H}-\mathrm{H}}=8.7 \mathrm{~Hz}\right), 3.02$ 
(s, $1 \mathrm{H}, \mathrm{HC} \equiv \mathrm{C}) .{ }^{13} \mathbf{C}-\mathbf{N M R}\left(75 \mathrm{MHz}, \mathrm{CDCl}_{3}\right) \delta: 195.7,161.8,139.9,137.2,120.4,117.8,117.0$, 82.3, 81.7.

5-bromo-3-(tert-butyl)-2-hydroxybenzaldehyde (3b). (1) In a dry two-necked flask, under

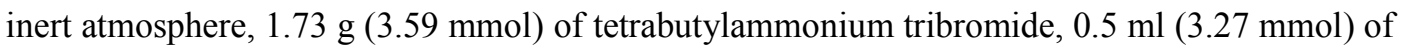
2-(tert-butyl)phenol and $26 \mathrm{ml}$ of anhydrous $\mathrm{CH}_{2} \mathrm{Cl}_{2}$ were added. The mixture was stirred at room temperature until the disappearance of the starting material that was monitored by TLC. Then, the mixture was extracted with $\mathrm{Et}_{2} \mathrm{O} / \mathrm{H}_{2} \mathrm{O}$ and washed with $\mathrm{HCl} 1 \mathrm{M}(2 \times 10 \mathrm{ml})$ and brine $(2 \times 10 \mathrm{ml})$. The organic phase was dried over anhydrous $\mathrm{Na}_{2} \mathrm{SO}_{4}$ and the solvent was removed under reduced pressure. $741 \mathrm{mg}$ (3.24 mmol) of 4-bromo-2-(tert-butyl)phenol, as a yellow oil, were obtained. Yield $99 \%$.

GC-MS m/z (+) $228(\mathrm{M}, 100 \%)$.

${ }^{1}$ H-NMR $\left(200 \mathrm{MHz}, \mathrm{CDCl}_{3}\right) \delta: 7.36\left(\mathrm{~d}, 1 \mathrm{H}, \mathrm{Ph},{ }^{4} \mathrm{~J}_{\mathrm{H}-\mathrm{H}}=2 \mathrm{~Hz}\right), 7.17\left(\mathrm{dd}, 1 \mathrm{H}, \mathrm{Ph},{ }^{3} \mathrm{~J}_{\mathrm{H}-\mathrm{H}}=8 \mathrm{~Hz}\right.$, $\left.{ }^{4} \mathrm{~J}_{\mathrm{H}-\mathrm{H}}=2 \mathrm{~Hz}\right), 6.56\left(\mathrm{~d}, 1 \mathrm{H}, \mathrm{Ph},{ }^{3} \mathrm{~J}_{\mathrm{H}-\mathrm{H}}=8 \mathrm{~Hz}\right), 4.84(\mathrm{~s}, 1 \mathrm{H}, \mathrm{OH}), 1.39\left(\mathrm{~s}, 9 \mathrm{H}, \mathrm{C}\left(\mathrm{CH}_{3}\right)_{3}\right)$.

${ }^{13}$ C-NMR $\left(20 \mathrm{MHz}, \mathrm{CDCl}_{3}\right)$ §:183.0, 138.3, 129.9, 129.3, 117.8, 112.6, 33.4, 34.5, 31.6, 29.06.

(2) Under inert atmosphere, in a dry two-necked flask, a solution of 4-bromo-2-(tertbutyl)phenol (700 mg, $3.05 \mathrm{mmol}), \mathrm{MgCl}_{2}(581 \mathrm{mg}, 6.1 \mathrm{mmol}), \mathrm{Et}_{3} \mathrm{~N}(0.8 \mathrm{ml}, 6.1 \mathrm{mmol})$ in 30 $\mathrm{ml}$ of anhydrous THF were stirred at room temperature for 30 minutes. Then, $456 \mathrm{mg}$ (18.2 mmol) of paraformaldehyde were added and the reaction mixture was stirred at $75^{\circ} \mathrm{C}$ overnight. After cooling at room temperature, the mixture was diluted with EtOAc $(30 \mathrm{ml})$ and washed with $\mathrm{HCl} 1 \mathrm{M}(5 \times 20 \mathrm{ml}), \mathrm{H}_{2} \mathrm{O}(5 \times 20 \mathrm{ml})$, brine $(5 \times 20 \mathrm{ml})$. The organic phase was dried over $\mathrm{Na}_{2} \mathrm{SO}_{4}$ and filtered. The crude was purified by chromatographic column on flash silica gel (Petroleum ether $\left.\left(40-70^{\circ} \mathrm{C}\right)\right)$ affording to $391 \mathrm{mg}(1.52 \mathrm{mmol})$ of product with $50 \%$ of yield.

GC-MS m/z (+) $257(\mathrm{M}, 100 \%)$.

${ }^{1}$ H-NMR $\left(300 \mathrm{MHz}, \mathrm{CDCl}_{3}\right) \delta: 11.71(\mathrm{~s}, 1 \mathrm{H}, \mathrm{OH}), 9.74(\mathrm{~s}, 1 \mathrm{H}, \mathrm{O}=\mathrm{CH}), 7.53\left(\mathrm{~d}, 1 \mathrm{H}, \mathrm{Ph},{ }^{4} \mathrm{~J}_{\mathrm{H}-\mathrm{H}}=\right.$ $2.4 \mathrm{~Hz}), 7.44\left(\mathrm{~d}, 1 \mathrm{H}, \mathrm{Ph},{ }^{4} \mathrm{~J}_{\mathrm{H}-\mathrm{H}}=2.7 \mathrm{~Hz}\right), 1.36\left(\mathrm{~s}, 9 \mathrm{H}, \mathrm{C}\left(\mathrm{CH}_{3}\right)_{3}\right)$.

${ }^{13}$ C-NMR (75 MHz, $\left.\mathrm{CDCl}_{3}\right) \delta: 195.6,189.8,170.7,136.6,133.3,121.3,110.8,34.8,28.7$.

3-(tert-butyl)-2-hydroxy-5-((trimethylsilyl)ethynyl)benzaldehyde (4b). Under inert atmosphere, in a dry two-necked flask, $391 \mathrm{mg}(1.52 \mathrm{mmol})$ of $\mathbf{3 b}, 30 \mathrm{mg}(0.04 \mathrm{mmol})$ of $\left[\mathrm{PdCl}_{2}\left(\mathrm{PPh}_{3}\right)_{2}\right]$ and $11 \mathrm{mg}(0.06 \mathrm{mmol})$ of $\mathrm{CuI}$ were added. After five vacuum-argon cycles, 5 $\mathrm{ml}$ of $\mathrm{Et}_{3} \mathrm{~N}$ and $0.3 \mathrm{ml}(2.33 \mathrm{mmol})$ of ethynyltrimethylsilane were added. The reaction mixture was stirred at $80^{\circ} \mathrm{C}$ for $6 \mathrm{~h}$. After cooling to room temperature, the mixture was filtered and the flask was washed with $\mathrm{CH}_{2} \mathrm{Cl}_{2}$. The crude product was purified, after removal the solvent under reduced pressure, by chromatographic column on flash silica gel (Petroleum ether $\left(40-70^{\circ} \mathrm{C}\right)$ ) affording to $346 \mathrm{mg}$ (1.26 mmol) of pale yellow oil with $83 \%$ of yield.

GC-MS m/z (+) 274 (M, 100\%). 
${ }^{1}$ H-NMR $\left(300 \mathrm{MHz}, \mathrm{CDCl}_{3}\right) \delta: 11.89(\mathrm{~s}, 1 \mathrm{H}, \mathrm{OH}), 9.81(\mathrm{~s}, 1 \mathrm{H}, \mathrm{O}=\mathrm{CH}), 7.58\left(\mathrm{~d}, 1 \mathrm{H}, \mathrm{Ph},{ }^{4} \mathrm{~J}_{\mathrm{H}-\mathrm{H}}=\right.$ $2.1 \mathrm{~Hz}), 7.54\left(\mathrm{~d}, 1 \mathrm{H}, \mathrm{Ph},{ }^{4} \mathrm{~J}_{\mathrm{H}-\mathrm{H}}=2.1 \mathrm{~Hz}\right), 1.38\left(\mathrm{~s}, 9 \mathrm{H}, \mathrm{C}\left(\mathrm{CH}_{3}\right)_{3}\right), 0.24\left(\mathrm{~s}, 9 \mathrm{H}, \mathrm{Si}\left(\mathrm{CH}_{3}\right)_{3}\right)$.

${ }^{13}$ C-NMR $\left(75 \mathrm{MHz}, \mathrm{CDCl}_{3}\right) \delta: 196.3,161.1,138.4,137.1,135.4,120.0,113.9,103.7,92.7$, $34.6,28.8,-0.3$.

3-(tert-butyl)-5-ethynyl-2-hydroxybenzaldehyde (5b). In a one-necked flask, $300 \mathrm{mg}$ (1.09 mmol) of $3 \mathbf{b}, 1.2 \mathrm{ml}(1.20 \mathrm{mmol}, 1.1 \mathrm{eq})$ of TBAF (1 M solution in THF) and $62 \mu \mathrm{l}$ of acetic acid were added. After $3 \mathrm{~h}$ under stirring at room temperature, the reaction mixture was diluted with $\mathrm{CH}_{2} \mathrm{Cl}_{2}$ and washed with water until $\mathrm{pH}=7$ of the aqueous phase. The organic phase was dried over anhydrous $\mathrm{Na}_{2} \mathrm{SO}_{4}$, the solvent was removed under reduced pressure affording to 198 $\mathrm{mg}(0.98 \mathrm{mmol})$ of a pale yellow oil. Yield $90 \%$.

GC-MS m/z (+) 202 (M, 100\%).

${ }^{1}$ H-NMR $\left(300 \mathrm{MHz}, \mathrm{CDCl}_{3}\right) \delta: 11.92(\mathrm{~s}, 1 \mathrm{H}, \mathrm{OH}), 9.83(\mathrm{~s}, 1 \mathrm{H}, \mathrm{O}=\mathrm{CH}), 7.61\left(\mathrm{~d}, 1 \mathrm{H}, \mathrm{Ph},{ }^{4} \mathrm{~J}_{\mathrm{H}-\mathrm{H}}=\right.$ $2.1 \mathrm{~Hz}), 7.56\left(\mathrm{~d}, 1 \mathrm{H}, \mathrm{Ph},{ }^{4} \mathrm{~J}_{\mathrm{H}-\mathrm{H}}=2.1 \mathrm{~Hz}\right), 3.00(\mathrm{~s}, 1 \mathrm{H}, \mathrm{C} \equiv \mathrm{CH}), 1.40\left(\mathrm{~s}, 9 \mathrm{H} \mathrm{C}\left(\mathrm{CH}_{3}\right)_{3}\right)$.

${ }^{13}$ C-NMR (75 MHz, $\mathrm{CDCl}_{3}$ ) $\delta:$ 196.3, 161.3, 138.7, 137.2, 135.4, 120.1, 112.8, 82.4, 35.0, 28.7.

Compound 1. Compound 5a (51 mg, $0.35 \mathrm{mmol}), 1,2$-phenylendiamine (18 mg, $0.17 \mathrm{mmol})$ and $(\mathrm{AcO})_{2} \mathrm{UO}_{2} \cdot 2 \mathrm{H}_{2} \mathrm{O}(84 \mathrm{mg}, 0.20 \mathrm{mmol})$ were added in a one-necked flask dissolving in a minimum amount of $\mathrm{CH}_{3} \mathrm{OH}$. After 5' an orange-red solid precipitates. The reaction mixture was stirred at room temperature for $24 \mathrm{~h}$. Then, the solid was filtered and washed with pentane affording to $100 \mathrm{mg}(0.16 \mathrm{mmol})$ of product with a yield of $94 \%$.

${ }^{1}$ H-NMR (300 MHz, d ${ }_{6}$-DMSO) $\delta: 9.60(\mathrm{~s}, 2 \mathrm{H}, \mathrm{HC}=\mathrm{N}), 7.97\left(\mathrm{~d}, 2 \mathrm{H}, \mathrm{Ph},{ }^{4} \mathrm{~J}_{\mathrm{H}-\mathrm{H}}=2.4 \mathrm{~Hz}\right), 7.78$ $(\mathrm{m}, 2 \mathrm{H}, \mathrm{Ph}), 7.64\left(\mathrm{dd}, 2 \mathrm{H}, \mathrm{Ph},{ }^{3} \mathrm{~J}_{\mathrm{H}-\mathrm{H}}=8.7 \mathrm{~Hz},{ }^{4} \mathrm{~J}_{\mathrm{H}-\mathrm{H}}=2.4 \mathrm{~Hz}\right), 7.54(\mathrm{~m}, 2 \mathrm{H}, \mathrm{Ph}), 6.97(\mathrm{~d}, 2 \mathrm{H}, \mathrm{Ph}$, $\left.{ }^{3} \mathrm{~J}_{\mathrm{H}-\mathrm{H}}=8.7 \mathrm{~Hz}\right), 3.92(\mathrm{~s}, 2 \mathrm{H}, \mathrm{C} \equiv \mathrm{CH})$,

${ }^{13}$ C-NMR (75 MHz, $\left.\mathrm{CD}_{3} \mathrm{COCD}_{3}\right) \delta: 170.5,166.6,176.6,139.4,138.9,129.3,124.3,121.5$, $120.7,109.8,83.5,78.9$.

MS-ESI-TOF for $\mathrm{C}_{24} \mathrm{H}_{17} \mathrm{~N}_{2} \mathrm{O}_{4} \mathrm{NaU}$ calcd 655.1359 , found $655.1334 \mathrm{~m} / \mathrm{z}^{+}$.

Compound 2. Compound $5 \mathbf{b}$ (65 mg, $0.32 \mathrm{mmol})$, 1,2-phenylendiamine (17 mg, $0.16 \mathrm{mmol})$ and $(\mathrm{AcO})_{2} \mathrm{UO}_{2} \cdot 2 \mathrm{H}_{2} \mathrm{O}(80 \mathrm{mg}, 0.19 \mathrm{mmol})$ were added in a one-necked flask dissolving in a minimum amount of $\mathrm{CH}_{3} \mathrm{OH}$. After 5' a red solid precipitates. The reaction mixture was stirred at room temperature for $24 \mathrm{~h}$. Then, the solid was filtered and washed with pentane affording to $92 \mathrm{mg}(0.12 \mathrm{mmol})$ of product with a yield of $75 \%$.

${ }^{1}$ H-NMR (300 MHz, d ${ }_{6}$-DMSO) $\delta: 9.62(\mathrm{~s}, 2 \mathrm{H}, \mathrm{HC}=\mathrm{N}), 7.87$ (d, 2H, Ph, $\left.{ }^{4} \mathrm{~J}_{\mathrm{H}-\mathrm{H}}=2.1 \mathrm{~Hz}\right), 7.75-$

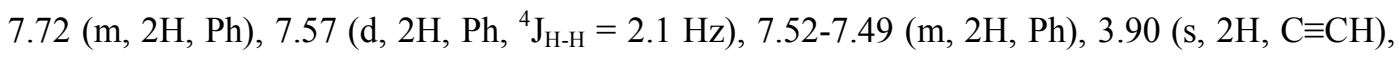
$1.68\left(\mathrm{~s}, 18 \mathrm{H}, \mathrm{C}\left(\mathrm{CH}_{3}\right)_{3}\right)$.

${ }^{13}$ C-NMR (75 MHz, $\mathrm{d}_{6}$-DMSO) $\delta:$ 169.6, 167.1, 176.8, 170.9, 138.2, 135.2, 129.0, 125.1, 120.6, $109.1,84.0,78.5,33.8,35.3,30.9,29.9$. 
MS-ESI-TOF for $\mathrm{C}_{32} \mathrm{H}_{30} \mathrm{~N}_{2} \mathrm{O}_{4} \mathrm{NaU}$ calcd 767.2611 , found $767.2586 \mathrm{~m} / \mathrm{z}^{+}$.

1

2

3

4

5

6

7

8

9

10

11

12

13

14

15

16

17

18

19

20

21

22

23

24

25

26

27

28

29

30

31

32

33

34

35

36

37

38

39

40

41

42

43

44

45

46

47

48

49

50

51

52

53

54

55

56

57

58

59

60

URL: http:/mc.manuscriptcentral.com/tandf/gsch Email: gsch-peerreview@tandf.co.uk 


\section{Computational details}

All calculations were carried out with the Gaussian $03^{1}$ package of programs at the DFT-B3LYP computational level. The basis set was chosen as follows: for chlorine, bromine and uranium the LANL2DZ basis ${ }^{2,3,4}$ was used. For carbon, hydrogen, fluorine, oxygen and nitrogen the 6$31 \mathrm{G}(\mathrm{d}, \mathrm{p})$ basis including polarization functions for the non-hydrogen atoms was chosen. Geometries have been optimized in vacuum, without including any symmetry constraints. Solvent effects have been included using the CPCM (polarizable conductor calculation) method on the previously optimized species. ${ }^{5}$
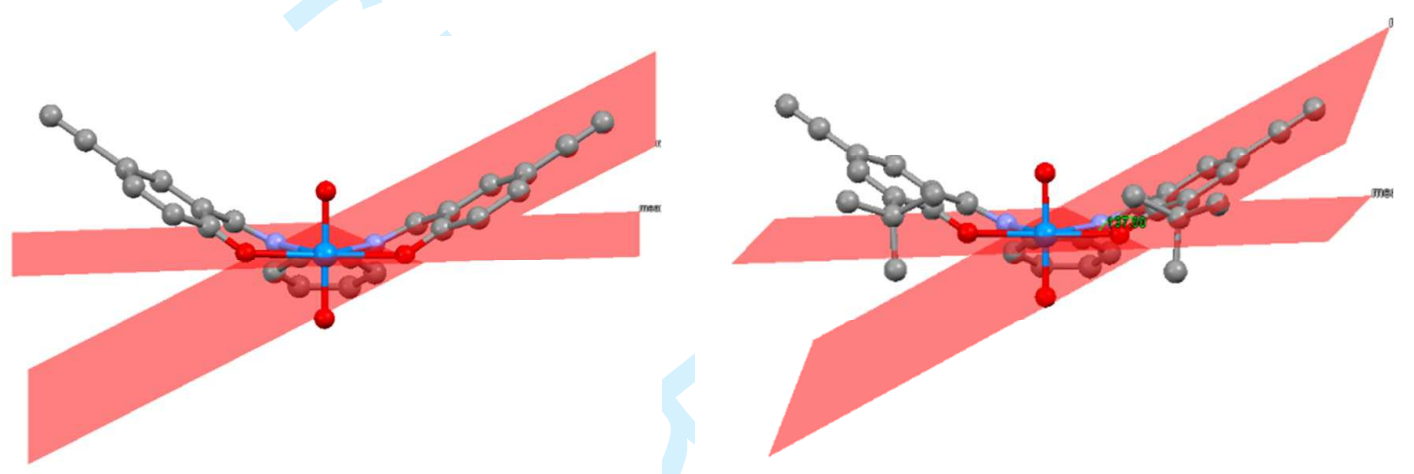

Figure S1. Optimized geometries of 1 (left) and 2 (right) showing the dihedral angles between main planes. Hydrogen atoms are omitted for clarity.
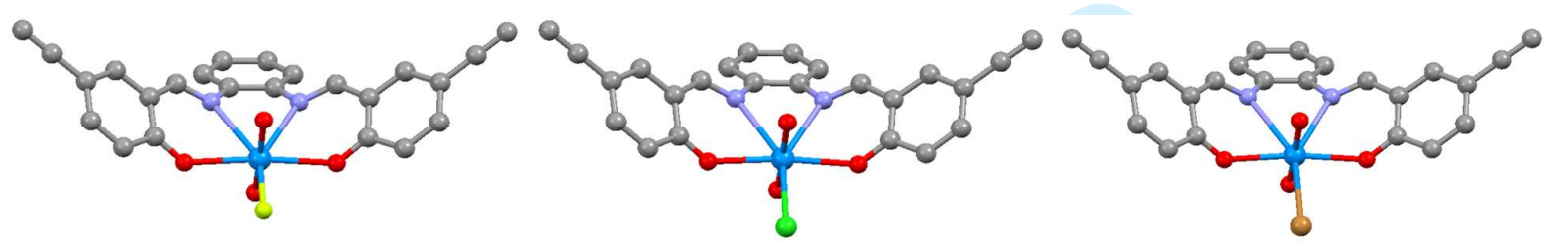

Figure S2. Optimized geometries of 1 with $\mathrm{F}^{-}$(left), $\mathrm{Cl}^{-}$(middle) and $\mathrm{Br}^{-}$(right). Hydrogens are omitted for clarity. Carbon (grey); oxygen (red); uranium (pale blue); nitrogen (dark blue); fluoride (yellow); chloride (green) and bromide (brown).

\footnotetext{
${ }^{1}$ M.J. Frisch, G.W. Trucks, H.B. Schlegel, G.E. Scuseria, M.A. Robb, J.R. Cheeseman, et al. Gaussian 03, revision C.02. Wallingford CT: Gaussian, Inc.; 2004.

${ }^{2}$ W. R. Wadt, P.J. Hay J Chem Phys 1985, 82, 284-98.
} 


\footnotetext{
${ }^{3}$ W. R. Wadt, P. J.Hay J. Chem. Phys. 1985, 82, 299-301.

${ }^{4}$ J. Otriz, , P. Hay, R. Martin J. Am. Chem. Soc. 1992, 114, 2736-7.

${ }^{5}$ M. Cossi, N. Rega, G. Scalmani, V. Barone J. Comput. Chem. 2003, 24, 669-81.
} 